\title{
An overview of international wildlife trade from Southeast Asia
}

\author{
Vincent Nijman
}

Received: 3 September 2009/ Accepted: 1 December 2009/Published online: 23 December 2009

(C) The Author(s) 2009. This article is published with open access at Springerlink.com

\begin{abstract}
Wildlife trade is the very heart of biodiversity conservation and sustainable development providing an income for some of the least economically affluent people and it generates considerable revenue nationally. In Asia the unsustainable trade in wildlife has been identified as one of the main conservation challenges. Internationally, wildlife trade is regulated through the Convention on International Trade in Endangered Species of wild fauna and flora (CITES) to which all Southeast Asian nations are signatory. I obtained data on international trade in CITES-listed animals in the period 1998-2007. In all $>35$ million animals ( 0.3 million butterflies; 16.0 million seahorses; 0.1 million other fish; 17.4 million reptiles; 0.4 million mammals; 1.0 million birds) were exported in this period, 30 million ( $\sim 300$ species) of them being wild-caught. In addition 18 million pieces and 2 million kg of live corals were exported. Malaysia, Vietnam, Indonesia and China are the major exporters of wild-caught animals and the European Union and Japan are the most significant importers. Over this period exports in birds significantly decreased, trade in the other taxa either increased or remained stable. For all taxa but butterflies the vast majority of individuals represent wild-caught individuals. Records of illegal or undeclared international trade are scant but can be significantly larger than levels of official exports. It is concluded that there is an urgent need for better assessments of what levels of exploitation are sustainable (including exploring appropriate proxies for Non Detriment Findings), for initiatives to make regulatory mechanisms more effective (including the introduction of minimum mandatory standards and monitoring selected wildlife trade hubs), and for better licensing and registration. Funding for at least some of these initiatives can be obtained by imposing small levies on exports of CITES-listed wildlife.
\end{abstract}

Keywords Biodiversity · Conservation - CITES · Sustainable livelihoods · Trade regulations

V. Nijman

Zoological Museum Amsterdam, PO Box 94766, 1090 GT Amsterdam, the Netherlands

V. Nijman $(\square)$

Oxford Wildlife Trade Research Group, School of Social Sciences and Law,

Oxford Brookes University, Oxford OX3 0BP, UK

e-mail: vnijman@brookes.ac.uk 


\section{Introduction}

Recently McNeely et al. (2009) identified what they, as the Asia Section of the Society for Conservation Biology, saw as the main challenges to biodiversity conservation in Asia. They noted that Asia is going through an interesting but challenging age because economic development is spreading quickly in many countries (most notably the substantial investments in infrastructure in India and China) with cities expanding rapidly in most countries, and identified curbing the trade in endangered species of plants and animals and using conservation biology to build a better understanding of the spread of zoonotic diseases (this being intrinsically linked to wildlife trade) as two of these main challenges. The impact of unsustainable and ill-regulated wildlife trade in Southeast Asia, and the importance of curbing it, was furthermore recently highlighted by two World Bank initiated reports (Grieser-Johns and Thomson 2005; TRAFFIC 2008). Southeast Asiaincluding China's international borders and parts of Indonesia- has been identified as a 'wildlife trade hotspots' i.e. a region where wildlife trade poses a disproportional large threat (Davies 2005; TRAFFIC 2008; see also Sodhi et al. 2004).

Wildlife trade includes all sales or exchanges of wild animal and plant resources by people, and is the very heart of biodiversity conservation and sustainable development (Broad et al. 2003; Abensperg-Traun 2009). Wildlife trade involves live animals and plants or a diverse range of products needed or prized by humans-including skins, medicinal ingredients, food-and may provide an income for some of the least economically affluent people and generates considerable revenue nationally ( $\mathrm{Ng}$ and Tan 1997; Shunichi 2005; TRAFFIC 2008). The primary motivating factor for wildlife traders is economic, ranging from small-scale local income generation to major profit-oriented business. While most wildlife is traded locally, and the majority nationally (that is within the political borders of a country or state) there is a large volume of wildlife that is traded internationally (Green and Shirley 1999; Wood 2001; Stoett 2002; Auliya 2003; WCS and TRAFFIC 2004; Blundell and Mascia 2005; Schlaepfer et al. 2005; Nijman and Shepherd 2007). Between collectors of wildlife and the ultimate users, any number of middlemen may be involved in the wildlife trade, including specialists involved in storage, handling, transport, manufacturing, industrial production, marketing, and the export and retail businesses, and these may operate both domestically and internationally (TRAFFIC 2008).

Intrinsically linked to economic growth the demand for wildlife has increased, and, exacerbated by ongoing globalisation, the scale and extent of wildlife trade likewise may have enlarged. Population growth, increasing buyer power, and globalisation have led to a rise in demand for exotic wildlife (hence international trade) and this has occurred in developed, emerging and developing nations alike. In the absence of strong regulatory mechanisms, and given large monetary gains, these demands will be fulfilled, putting a strain on wildlife populations.

While levels of wildlife trade are rarely quantified and specified, it is clear that for many species groups from different areas huge volumes are traded annually (Li and Li 1998; van Dijk et al. 2000; Auliya 2003; Zhou and Jiang 2004, Schlaepfer et al. 2005; Engler and Parry-Jones 2007). Probably the species groups and individual taxa for which we have the most detailed data are the ones that are of conservation concern, but some arguable much better than others. Not only have these taxa received the attention from both government and non-government organizations monitoring the extraction from the wild, trade in a significant number of them are regulated (and systematically recorded) through the Convention on International Trade in Endangered Species of Wild Fauna and Flora (CITES), allowing retrospective assessments of realised levels of trade. While by their very nature 
rare animals and plants tend to be traded in smaller absolute numbers, especially when levels of trade are capped, from a conservation perspective it may be more meaningful to restrict the analysis of levels of wildlife trade to conservation-dependent species or species groups.

Presented here is an analysis of trade in a wide range of CITES-listed animal groups (from butterflies and corals to reptiles and birds) with the ultimate aim of assessing the levels of extraction from the wild needed to supply the international demand in wildlife. An assessment is made of temporal changes in volumes, the mayor (official) exporters and importers for the different taxa are identified, and data on volumes bred under captive or controlled conditions is consolidated. It shows that for essentially for all taxa but butterflies the majority of individuals in trade are derived from the wild and that apart from birds exports have either remained stable or have increased during the time period under investigation. Comparing these official data with scant data from illegal exports suggests that true levels of export are higher than reported, and that for selected taxa this will exceed sustainable levels of exploitation.

\section{Methods}

Study region

Southeast Asia is here defined on a country-by-country basis, and includes Indonesia (including East Timor prior to gaining independence in 2002), Brunei, Philippines, Malaysia, Thailand, Myanmar, Laos, Cambodia, Viet Nam and China (excluding Hong Kong Special Administrative Region [SAR], Macau SAR, or Taiwan, Province of China $[\mathrm{PoC}])$. Both Indonesia and China extend extensively beyond what is normally included in Southeast Asia. It was not possible to separate trade from the southernmost part of China (Yunnan, Guangxi, Guangdong, Hainan) and with that from other parts of China, nor to differentiate between exports from western (Sumatra, Java, Kalimantan) and eastern Indonesia (e.g. Moluccas, Papua), and given that both China and Indonesia proved to be significant wildlife exporters, both countries were included. Christmas Island-situated in the Indian Ocean south of Java and governed by Australia - is biogeographically part of Southeast Asia, and was included in the analysis. Exports of CITES-listed species from Christmas Island were very small compared to the other Southeast Asian countries.

\section{Data acquisition}

Data were obtained from the WCMC-CITES database (http://www.unep-wcmc.org/ citestrade, downloaded June 2009). This database reports all records of import export and re-export of CITES-listed species as reported by Parties. I limit this to the period 19982007, with 2007 being the most recent data available for analysis. During this period Laos (2004) joined CITES and its exports prior to their ascension to the Convention to nonCITES Parties may have been underreported. Note however that Laos export relatively small amounts of wildlife. For six animal groups (see below) I downloaded all exports from the ten Southeast Asian countries and Christmas Island, and transferred this to an excel database. I focus on records of exports that either reported individuals, or that could unambiguously be converted to individuals (thus excluding reports such as kilograms of horns, bones, scales, or litres of extracts, blood, derivatives, etc.). This initial download resulted in just over 53,000 entries, i.e. records of exports. A significant proportion of trade 
within Southeast Asia concerns re-exports, that is a shipment is imported from one Southeast Asian country to another, only to be re-exported to another country, either in Southeast Asia or elsewhere. In order to prevent double-counting, I excluded all re-exports from our analysis. Definitions in this paper follow those of CITES: 'captive-bred' refers to at least second generation offspring of parents bred in a controlled captive environment (or first generation offspring from a facility that is managed in a manner that has been demonstrated to be capable of reliably producing second-generation offspring in a controlled environment); 'F1 captive-bred' refers to specimens born in captivity to wild-caught parents and that are not considered as captive bred under CITES; 'ranch-raised' refers to specimens either directly removed from the wild and reared in a controlled environment or progeny from gravid females captured from the wild; 'wild-caught' refers to specimens that originate from the wild.

\section{Analysis}

The six animal groups included for analysis were butterflies, seahorses, fish (other than seahorses), reptiles (snakes, turtles, lizards), mammals and birds. These taxa were selected as a significant part of its trade represents live individuals, or trade is reported as such that it can be converted to individuals (skins, bodies). Quantities of skins exported were occasionally reported in metres and skins and life animals in $\mathrm{kg}$, and these were converted to individuals as follows: For seahorses I assumed, conservatively, that it takes 300 fresh seahorses to produce $1 \mathrm{~kg}$ of dried seahorses (cf. Grey et al. 2005); snake skins reported in metres were converted to individuals by assuming, arbitrarily and conservatively, an average length of $3 \mathrm{~m}$ per snake. Mauremys and Pelodiscus turtles, exported for their meat and reported in $\mathrm{kg}$, were converted to individuals by assuming, again somewhat arbitrarily but in all likelihood conservatively, an average weight of 0.5 and $1.0 \mathrm{~kg}$ for a Mauremys and a Pelodiscus turtle, respectively. Trade in crocodilians can be reported as back skins or belly skins, and these were counted only once taking the largest number.

In addition to the above-mentioned taxa live corals are traded in significant numbers from Southeast Asia; all are traded by the $\mathrm{kg}$ as well as in pieces. It was not meaningful to convert these to individuals, nor was it possible to convert pieces to $\mathrm{kg}$ or $\mathrm{kg}$ to pieces, and I duly report export volumes as included in the CITES database (cf. Bruckner 2001).

Each entry contained the following data: species; species group (seahorses, reptile, etc.); year of export (1998-2007); exporting country (this one of the 10 Southeast Asian countries); importing country; export quantity (reported in individuals, metres, or kilograms, converted to individuals); export purpose; export source (wild-caught [CITES source code $\mathrm{W}]$, born in captivity $[\mathrm{F}]$, captive-bred [C and $\mathrm{D}]$, ranch-raised [R]). In addition, records were kept of illegal trade (source code I) as reported by importing Parties.

Note that the reliability of the records in the CITES database is entirely dependent on the accuracy at which CITES Parties report these data. It has been well-documented that there are large discrepancies between officially reported import and export figures and the actual imports or export figures (Blundell and Mascia 2005; Nijman and Shepherd 2007; Chen et al. 2009), and indeed in the present analysis frequently reported quantities differed significantly between the importing and the exporting Party. Likewise, there are discrepancies between source codes, with switches between e.g. wild-caught and captive-bred, and for specific taxa from certain countries significant numbers of individuals declared as captive-bred are in fact wild-caught (see Nijman and Shepherd 2009 for a case study on the export of alleged captive-bred reptiles from Indonesia). In the present analysis it was not possible, however, to assess to what extent these discrepancies are intentional. 


\section{Results}

The data reveal the export of just over 35 million CITES-listed animals from Southeast Asian countries in a ten-year period from 1998 to 2007. Almost 30 million of these represent wild-caught individuals and $<4.5$ million are derived from captive-breeding facilities.

Table 1 shows the most significant exporting countries for wild-caught individuals for the different species groups. It shows that for seahorses, butterflies and corals over $90 \%$ of all exports originate from single countries (Thailand for seahorses, Malaysia for butterflies and Indonesia for corals) and that invariable the largest exporter typically supplies over $60 \%$ of the trade. For all species groups four countries (Malaysia, Vietnam, Indonesia and China) are the major exporters, and the European Union and Japan have been the most significant importers of wild-caught animals from Southeast Asia in the last decade. Similarly as for the exporters, albeit less marked, single countries dominate the markets (e.g. Hong Kong for the import of wild-caught seahorses and other fish and the European Union for wild-caught mammals and birds). China and Singapore, and to a lesser extent Malaysia, are the only Southeast Asian nations that features prominently as importers of wild-caught wildlife. It appears that China is the end destination for these imports, but Singapore (pangolin and reptile skins) and Malaysia (live birds) are less of consumer countries and-after processing-re-export the majority of their Southeast Asian imports.

Table 1 Exports and import of wild caught individuals from Southeast Asia listing for each major taxonomic group the three largest exporters in terms of volume (two if number three exports $<1 \%$ of the total volume) and the three largest importers

\begin{tabular}{|c|c|c|c|c|c|}
\hline Group & $\begin{array}{l}\text { Total number } \\
\text { of individuals }\end{array}$ & Exporters & Percentage & Importers & Percentage \\
\hline \multirow[t]{3}{*}{ Butterflies } & \multirow[t]{3}{*}{$13 \times 10^{3}$} & Malaysia & 98 & USA & 70 \\
\hline & & China & 2 & $\mathrm{EU}$ & 10 \\
\hline & & & & Canada & 8 \\
\hline \multirow[t]{3}{*}{ Seahorses } & \multirow[t]{3}{*}{$16 \times 10^{6}$} & Thailand & 94 & Hong Kong SAR & 57 \\
\hline & & Vietnam & 1 & Taiwan PoC & 24 \\
\hline & & & & China & 14 \\
\hline \multirow[t]{2}{*}{ Other fish } & \multirow[t]{2}{*}{$30 \times 10^{3}$} & Malaysia & 57 & Hong Kong SAR & 93 \\
\hline & & Indonesia & 38 & China & 2 \\
\hline \multirow[t]{3}{*}{ Reptiles } & \multirow[t]{3}{*}{$14 \times 10^{6}$} & Indonesia & 62 & Singapore & 57 \\
\hline & & Malaysia & 36 & $\mathrm{EU}$ & 12 \\
\hline & & & & Japan & 7 \\
\hline \multirow[t]{3}{*}{ Mammals } & \multirow[t]{3}{*}{$12 \times 10^{4}$} & China & 77 & $\mathrm{EU}$ & 66 \\
\hline & & Malaysia & 20 & Singapore & 20 \\
\hline & & Vietnam & 2 & Japan & 7 \\
\hline \multirow[t]{3}{*}{ Birds } & \multirow[t]{3}{*}{$27 \times 10^{4}$} & China & 61 & $\mathrm{EU}$ & 63 \\
\hline & & Vietnam & 17 & Japan & 19 \\
\hline & & Malaysia & 14 & Malaysia & 10 \\
\hline \multirow[t]{3}{*}{ Coral pieces } & \multirow[t]{3}{*}{$17 \times 10^{6}$} & Indonesia & 92 & USA & 61 \\
\hline & & Vietnam & 7 & $\mathrm{EU}$ & 21 \\
\hline & & & & Japan & 7 \\
\hline
\end{tabular}


Table 2 Exports of wildlife reported as 'Illegal' by importing Parties for the period 1998-2007 (Source: WCMC CITES trade database) with the main exporters indicated; note that animals do not necessarily originate from the country from where they were exported

\begin{tabular}{llll}
\hline Group & Total number of individuals & Exporter & Percentage \\
\hline Seahorses & $49 \times 10^{2}$ & China & 93 \\
Other fish & 221 & China & 64 \\
Reptiles & $21 \times 10^{4}$ & Singapore & 67 \\
Mammals & 79 & Vietnam & 33 \\
Birds & 291 & Indonesia & 55 \\
Coral & $66 \times 10^{2}$ pieces & Indonesia & 84 \\
& $77 \times 10^{2} \mathrm{~kg}$ & Vietnam & 99 \\
\hline
\end{tabular}

Levels of illegal trade in CITES-listed species the CITES trade database are generally low involving less than a quarter of a million individuals over the ten-year period (Table 2). Over $60 \%$ were reported, or re-exported, by Singapore, almost $30 \%$ by Malaysia, and $\sim 6 \%$ by the USA. The illegal trade through Singapore (reported origin mostly Indonesia) and Malaysia (reported origin mostly Thailand) almost exclusively involved the re-export of reptiles or reptile skins, presumably after being confiscated by the authorities.

\section{Butterflies}

A total of 306,000 butterflies were traded with 13,000 being wild-caught individuals, 109,000 originating from ranging operations, and a further 184,000 from captive-breeding facilities (Fig. 1a). Up until around 2002 numbers of ranch-raised, captive-bred and wildcaught were in a similar order of magnitude, but from 2003 onwards the number of butterflies derived from ranching operations doubled annually followed in 2004 by the doubling of export from captive-breeding facilities. Butterflies are mostly traded dead for the curio market (Collins and Morris 1985; New and Collins 1991). At least 34 species were traded with the most common genera traded are birdwings Troides (ca. 170,000 individuals) and Ornithoptera (ca. 129,000 individuals). The main exporters for this period were Indonesia, China, Philippines, and Malaysia, with the USA and the EU being the main importing countries. The increase in breeding farms as to produce the high-quality specimens demanded in trade has, at least in some countries, led to a significant decrease in the capture of wild-caught specimens. In the 1980s Collins and Morris (1985) reported that, globally, $<10 \%$ of trade volumes were derived from captive-breeding or ranching operations, but levels seem to have increase considerable in recent years, in Southeast Asia the least. It should be noted that while reported levels of trade in butterflies involves extensive volumes, New and Collins (1991) noted that trade is extremely difficult to monitor because of the ease with which 'papered' butterflies (that is, dead specimens with their wings folded and stored in envelopes before they are relaxed and pinned) can be transported. While some specimens demand high prices the majority of trade involves 'high volume-low value' species, and it is likely that trade in these species will be underreported.

\section{Seahorses}

A total of 15.95 million seahorses were traded, with 15.83 million comprising wild-caught individuals and 0.12 million from breeding farms (Fig. 1b). Of the latter, the two-thirds 


\section{A Butterflies}

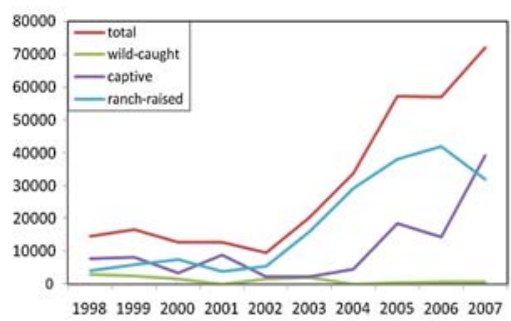

C Other Fish

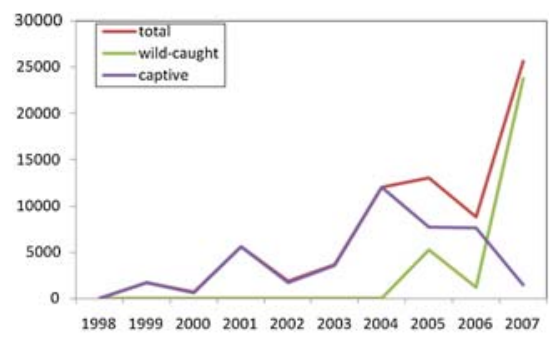

E Mammals

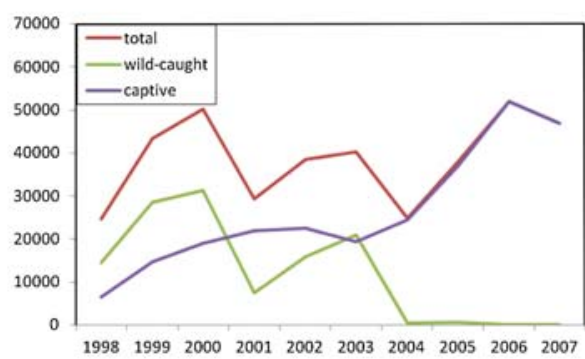

G Coral (pieces)

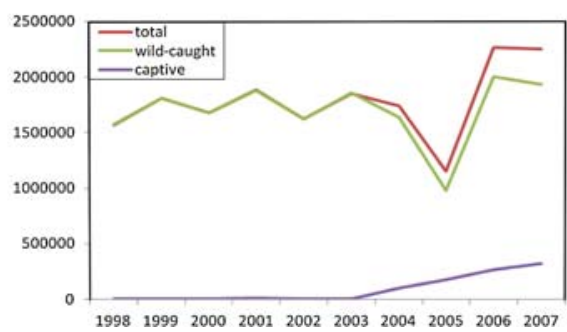

\section{B Seahorses}

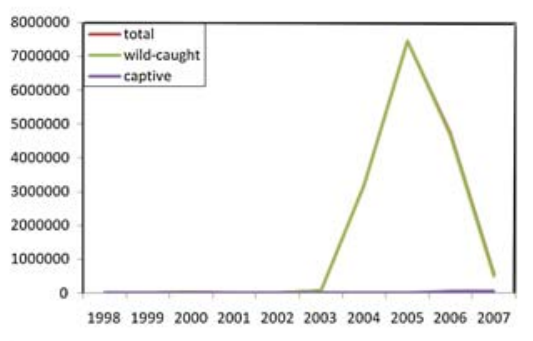

D Reptiles

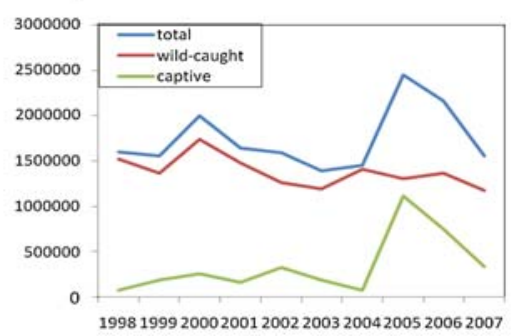

\section{F Birds}

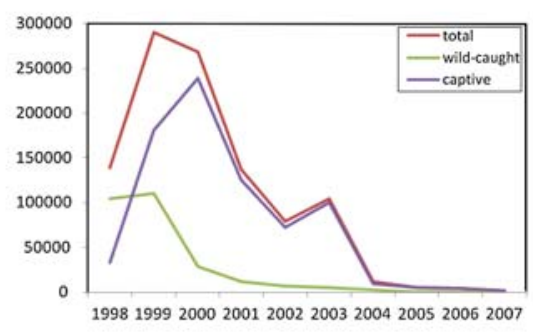

H Coral (kilograms)

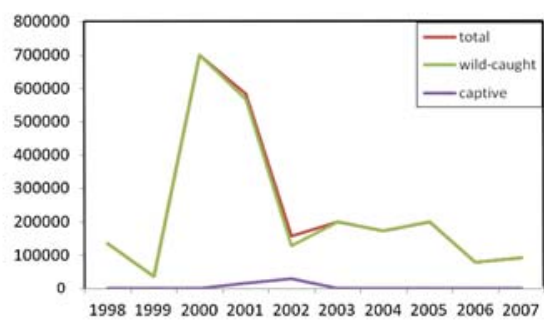

Fig. 1 Volumes of exports of CITES listed animals from Southeast Asia in the period 1998-2007. Captive refers to captive-bred animals (CITES source code C) and animals born under captive conditions (source code F), see text for details

were F1. The majority of seahorses were exported as dried specimens, i.e. 15.67 million individuals. Seahorses were only included on Appendix II of CITES in 2004, and indeed volumes reported prior to that year are markedly lower than from 2004 onwards. Numbers in 2007 were low compared to previous years and it is not clear whether or not this reflects 
under-reporting. If exports for the years 2004-2007 are representative for the period seahorses were not included in CITES the number of seahorses exported from Southeast Asia in the period 1998-2007 may have been well in close to 40 million individuals. The vast majority must have been extracted from the wild.

At least 19 species were traded with the most commonly traded species being Hippocampus kuda, H. trimaculatus and $H$. spinosissimus. Thailand and Vietnam export the largest volumes, with Thailand being responsible for over $90 \%$ of all reported trade (Table 1). However, scant data from a recent confiscation of a single shipment of dried seahorses in Poland, comprising of an estimated 1-2 million specimens, suggest true levels of export may be significantly higher than currently thought. It is noteworthy that this shipment originated from Indonesia. Indonesia reports low levels of export in seahorses but the fact that millions of seahorses were processed there and exported to Poland suggest considerable capacity to process seahorses. With respect to importing countries, China and its dependencies, Hong Kong SAR and Taiwan PoC are the main importers. Given that the bulk of seahorses are traded in the form of dried specimens destined for Traditional Chinese Medicine [TCM] (Vincent 1995), this is to be suspected, but given the case of confiscated seahorses in Poland this suggest that there is a high demand for TCM, or other forms of traditional medicine, outside China. Vincent (1995) noted that the in the early 1990s China, Taiwan and Hong Kong combined imported some 12 million seahorses annually (i.e. three times higher than reported here), and expressed concerns about supply not meeting demand. Likewise, Giles et al. (2006) reported the annual catch of some 2 million seahorses in Vietnam in the late 1990s, with the majority of these destined from export to China. If the reported levels of trade as obtained from the WCMC-CITES database are indeed a true reflection of the volumes exported, this then suggest either indeed a decrease in levels of trade or additional unreported trade.

\section{Other fish}

A total of 73,000 individuals of 10 CITES-listed species were traded, 30,000 from the wild and 42,000 from captive-breeding facilities (Fig. 1c). Napoleon Wrasse Cheilinus undulates (ca. 29,000) and Arapaima Arapaima gigas (ca. 28,000) were the most commonly traded species. A small number of fish are included on the appendixes of CITES and those CITES-listed species that are traded in significant volumes (such as sturgeon's caviar) do not originate from Southeast Asia. Sadovy (2005) remarked that listing of commercial fishes, historically, has rarely occurred under CITES which many governments feel is not a suitable convention for fish, with the Food and Agriculture Organization (FAO) of the United Nations being seen as the only appropriate body for dealing with fishes. In recent years some species have been included on the appendixes of CITES. For instance, the Napoleon Wrasse was included on Appendix II in 2005, with levels of off-take as to supply the Chinese and Hong-Kong SAR food markets posing a potential threat (Sadovy et al. 2003). Ng and Tan (1997) noted that several species of freshwater fish, such as the bala shark Balantiocheilos melanopterus, arowana Scleropages formosus and harlequin rasbora Rasbora heteromorpha, were severely over-exploited as to supply the demand for aquarium trade; of these only the arowana is listed on CITES.

The main traders for the period 1998-2007 of CITES-listed fish were Malaysia and Indonesia with China and Hong Kong SAR being the main importers. CITES-listed fish species are traded for a variety of reasons, including the aquarium markets and human consumption, but while compared to other taxa, volumes are almost insignificant, for 
individual species and populations, current levels of trade may still exceed sustainable levels of off-take.

\section{Reptiles}

A total of 17.43 million reptiles were traded, with 13.79 million individuals from the wild, and 3.51 million from captive-breeding or ranching facilities (Fig. 1d). At least 156 species, of which 65 are represented by wild-caught individuals, were traded from Southeast Asian countries in this period. The most commonly traded turtle genera were softshell turtles Pelodiscus (1.3 million) and box turtles Cuora $(520,000)$, the most common snake genera cobras Naja (1.8 million) and pythons Python (1.2 million) and the most common lizards, monitors Varanus (8.1 million) and crocodiles Crocodillus (400,000). Turtles are traded mainly for their meat or for their carapaces to be used in TCM, snakes, lizards, and crocodilians are traded by and large for their skins, but, the former also in significant volumes for the international pet market. Indonesia and Malaysia were the major exporters in terms of volumes, with Singapore as the major importer followed by the EU and Japan. I expect that a significant part of the imports of skins and raw products into Singapore are exported after being processed. Real levels of trade are expected to be significantly higher. Schoppe (2009) recently assessed levels of exploitation of box turtles (Cuora spp.) in Indonesia and estimated that some 2 million were exported annually; given that the official quota amounted only 18,000 individuals, the majority of turtles were exported undeclared. Similar figures were reported by Nijman et al. (in press) who estimated that trade in Tockay geckos Gekko gekko from Java amounted to some 1.2 million individuals a year, greatly exceeding the quota of 25,000 set by the Indonesian authorities. Wang et al. (1996) reported annual imports of 2 million $\mathrm{kg}$ of snakes [representing 200 to 400,000 animals] from Myanmar to China and Shepherd (2000) reported the annual export of $\sim 1$ million $\mathrm{kg}$ of Asiatic softshell turtles Amyda cartilaginea from Indonesia to China [representing $\sim 200$ to 300,000 individuals].

\section{Mammals}

A total of 388,000 mammals were traded, 120,000 from the wild and 264,000 from captive-breeding facilities (Fig. 1e). The wild-caught species represent at least 16 species. Trends in mammal exports are erratic with total volumes fluctuating between 25,000 and 50,000 individuals annually. Over the ten year period an ever-decreasing proportion derived from the wild, to such an extent that in the period 2004-2007 less than 1\% of mammals exported from Southeast Asia was reported as wild-caught. While the (illegal) exports of high profile species such as tigers, bears and elephants receive attention (Stiles 2004; Dinerstein et al. 2007; Shepherd and Nijman 2008; Nijman 2009) the most dominant mammal genera exported legally were macaques Macaca with ca. 270,000 individuals and leopard cats Prionailurus with ca. 91,000 individuals. The main exporters are China and Malaysia, with the EU and Singapore as the main importers. Reported exports of mammals are by and large for their skins, or, in the case of macaques, to be used in the biomedical industry, but recent reports of seizures of pangolins (Manis spp.) in Southeast Asia (Table 3) suggest that exports for meat and TMC (pangolin scales) are more significant than official data indicate (Pantel and Chin 2009). Exports of mammals within Southeast Asia, especially for the 'wild meat' markets may have been reduced in recent years following the outbreak of SARS (this being linked to wildlife trade: Bell et al. 2004) and 
Table 3 Examples of large volumes of wildlife confiscated or exported illegally above set quotas

\begin{tabular}{|c|c|c|c|c|}
\hline Taxa & Origin & Period & Individuals & Comments \\
\hline Seahorses & Indonesia & Aug 2009 & $\begin{array}{l}1,000,000- \\
2,000,000^{\mathrm{a}}\end{array}$ & Dried, confiscated in Poland \\
\hline $\begin{array}{l}\text { Monitor } \\
\text { lizards }\end{array}$ & Malaysia & $\begin{array}{l}\text { Nov 2008-Sep } \\
2009\end{array}$ & 15,332 & \\
\hline Geckos & Indonesia & Nov 2006 & $1,200,000$ & $\begin{array}{l}\text { Annual, illegal export in dried } \\
\text { specimens }\end{array}$ \\
\hline \multirow[t]{2}{*}{ Tortoises } & Indonesia & 2008 & $2,000,000$ & Annual, illegal export \\
\hline & Malaysia & 2008 & 22,000 & Annual, illegal export \\
\hline \multirow[t]{3}{*}{ Snakes } & Malaysia & May 2009 & 160 & \\
\hline & Indonesia & Jan 2006 & 100,000 & Annual, exports above set quota \\
\hline & Myanmar & 1999 & $400,000^{\mathrm{b}}$ & Annual export through Ruili, China \\
\hline Owls & Malaysia & $\begin{array}{l}\text { Nov 2008-Sep } \\
2009\end{array}$ & 1500 & Carcasses \\
\hline \multirow[t]{3}{*}{ Pangolins } & Indonesia & $\begin{array}{l}\text { Feb 2008-Jan } \\
2009\end{array}$ & $5300^{c}$ & \\
\hline & Vietnam & 2006 & 4000 & Seized in China \\
\hline & Thailand & Jan 2008 & 275 & \\
\hline \multirow[t]{3}{*}{ Corals } & Malaysia & Sep 2007 & $350 \mathrm{pcs}$ & Confiscated in UK \\
\hline & Philippines & Nov 2007 & $500 \mathrm{pcs} / 5,000 \mathrm{~kg}$ & Confiscated in Argentina \\
\hline & Philippines & Feb 2009 & $40,000 \mathrm{~kg}$ & Confiscated in USA \\
\hline
\end{tabular}

$\overline{{ }^{a}}$ Based on 14,000 kg dried specimens; ${ }^{b}$ based on 2 million kg of snakes ( 27 species); ${ }^{\mathrm{c}}$ based on 42,400 kg fresh carcasses

Sources: Wang et al. (1996), Liou (2007), Pantel and Chin (2009), Schoppe (2009), Shepherd and Shepherd (2009), TRAFFIC International (www.traffic.org, accessed 30 August 2009), Nijman et al. (in press) and Shepherd (in litt)

even avian influenza (Roberton et al. 2006), but given that it appears that much of this trade goes unreported or does not involve CITES-listed species it is unclear to what extent.

Birds

A total of 1.04 million birds were exported, 269,000 from the wild and 772,000 from captive-breeding facilities (Fig. 1f). Especially from 2000 onwards the vast majority of birds were reportedly derived from captive facilities. After an initial increase from 1998 to 1999, exports of birds from Southeast Asia has seen a progressive decline, to such an extent that exports of birds in the years 2004-2007 are virtually non-existent. In total at least 285 species, including 57 wild-caught, are traded. The most commonly traded genera were leiothrix babblers Leiothrix (ca. 170,000 individuals) and hill mynas Gracula religiosa (69,000 individuals). Main exporters were China, Vietnam and Malaysia with the EU, Japan and Malaysia as the main importers (Table 1). Partially in response to the outbreak of avian influenza the EU in 2005 severely restricted imports of birds, and with imports into Malaysia being partially for re-exports, the export of birds from Southeast Asia has come to an almost complete halt. There has been a discussion on whether blanket bans on bird trade are appropriate and effective (see e.g. Cooney and Jepson 2006; Gilardi 2006; Roe 2006) but at least locally levels of trade in wild-caught birds have declined (Shepherd 2006). 
Coral

A total of 17.83 million pieces of coral and 2.36 million $\mathrm{kg}$ of live coral were traded in the period 1998-2007 (Fig. 1g, h); representing at least 90 species that are wild-caught. Over this period the vast majority has been derived from the wild, but from 2003 onwards exports of coral from mariculture has seen a progressive increase. Only Indonesia, Malaysia and Viet Nam report export of corals from mariculture; Indonesia exports mariculture coral as ranch-raised whereas Viet Nam and Malaysia exports it as captivebred. Imports of corals are difficult to monitor accurately, and indeed. Blundell and Mascia (2005) found that the CITES trade database showed an almost $400 \%$ higher level of trade in corals than USA customs, and Wells and Barzdo (1991) have argued that CITES probably has a limited role to play for wide-ranging marine species such as many species of coral. As noted by Bruckner (2001) tracking trade using the CITES Trade Database provides limited information, because coral is reported to genus, and volume is reported by item or weight, the CITES mechanism, however, may promote the development of strategies to protect corals. While certain Southeast Asian countries have developed management plans for the sustainable harvest of corals, this mainly targets CITES-listed species, and hitherto its effectiveness has not been assessed.

\section{Conclusions and recommendations}

Wildlife in Southeast Asia is under attack from numerous angles: habitat loss and degradation, global climate change, commercial hunting, competition with introduced species (McNeely et al. 2009; Sodhi et al. 2004; Bickford et al. this issue; Wilcove and Koh this issue), etc. and these all act in concert potentially leading to the extinction of populations, species, and ecosystems. For most species, wildlife trade should be seen as just one of the actors in this complex interaction.

Trade in CITES-listed species of wildlife from Southeast Asia involved millions of animals annually, with the overwhelming majority of animals being derived from the wild. For most taxa there is no or limited data available on what level of extraction is biologically sustainable, and it is difficult to draw conclusions on the impact that high levels of trade may have on wild populations. CITES-listed species are generally the ones that are of global conservation concern, uncommon, or at least the ones for which regulation of trade levels was deemed necessary as to prevent overexploitation, and the large quantities of trade in them may warrant further monitoring. In order to obtain a picture of true levels of trade, one needs to add those species that are not regulated by CITES (often the more 'common' species, traded in large quantities, including many marine species), illegal exports (often involving considerable numbers with those numbers included in Table 3 representing the tip of the iceberg), and domestic trade (involving large quantities: e.g. Lee et al. 2005; Shepherd 2006).

While CITES calls for Non Detriment Findings (NDFs) to be made for each individual species in trade (even extending it to the local, population, levels), the scale of the trade in wild-caught individuals ( $\sim 30$ million over a 10-year period), the number of species involved $(\sim 300)$ and the lack of even the most basic data on e.g. population numbers for many taxa, makes this impractical in the Southeast Asian context. Nevertheless, efforts need to be stepped up in making proper NDFs, or finding appropriate proxies for them, the funds of which could be obtained by imposing small levies on exports of CITES-listed wildlife. This study tried to quantify levels of international trade from Southeast Asia by 
focussing on the number of individuals involved. This invariably will lead to a greater emphasis on some of the smaller taxa where trade in small volumes may involve large numbers of individuals (e.g. seahorses). Biologically it may, eventually, be more meaningful to quantify the total biomass that gets extracted from the wild as to supply the demands for international trade.

Numerous studies have concluded that regulation of wildlife trade laws within Asia, be it in relation to international or domestic trade, are insufficient (van Dijk et al. 2000; Nooren and Claridge 2001; Davies 2005; Lee et al. 2005; Giles et al. 2006; Nijman 2006; Nekaris and Nijman 2007; Shepherd and Nijman 2007a, b; Eudey 2008; Zhang et al. 2008), and there is an urgent need for initiatives to make regulatory mechanisms more effective. Proper licensing and registration within all sectors of the industry, together with introduction of mandatory minimum standards and appropriate training and inspection schemes need to be introduced (cf. Woods 2001; Shepherd and Nijman 2007a). With respect to monitoring both legal and illegal trade it is important to realize that most wildlife trade streams pass through a limited number of trade hubs. As noted by Karesh et al. (2007) these hubs do provide ample opportunities to maximize the effects of regulatory efforts as demonstrated with domestic animal trading systems (processing plants and wholesale and retail markets, for example).

Acknowledgements I thank Drs. Lian Pin Koh and Navjot S. Sodhi for inviting me to contribute to this special issue, and Chris R. Shepherd for data and encouragement to write this overview. Help from John R. Caldwell, WCMC-CITES trade database manager, with downloading trade data is much appreciated. I thank TRAFFIC Southeast Asia for providing facilities when writing this paper. Dr. Peter W. Kirby and two reviewers provided constructive comments, considerably improving the paper.

Open Access This article is distributed under the terms of the Creative Commons Attribution Noncommercial License which permits any noncommercial use, distribution, and reproduction in any medium, provided the original author(s) and source are credited.

\section{References}

Abensperg-Traun M (2009) CITES, sustainable use of wild species and incentive-driven conservation in developing countries, with an emphasis on southern Africa. Biol Conserv 142:948-963

Auliya M (2003) Hot trade in cool creatures: a review of the live reptile trade in the European Union in the 1990s. TRAFFIC Europe, Brussels

Bell D, Roberton S, Hunter PR (2004) Animal origins of SARS coronavirus: possible links with the international trade in small carnivores. Phil Trans R Soc Lond B 359:1107-1114

Bickford D, Howard SD, Ng DJJ, Sheridan JA (this issue) Impacts of climate change on the amphibians and reptiles of Southeast Asia. Biodivers Conserv

Blundell AG, Mascia MB (2005) Discrepancies in reported levels of international wildlife trade. Conserv Biol 19:2020-2025

Broad S, Mulliken T, Roe D (2003) The nature and extent of legal and illegal trade in wildlife. In: Oldfield S (ed) The trade in wildlife. Regulation for conservation. Flora and Fauna International Resource Africa and TRAFFIC International, London, pp 3-22

Bruckner AW (2001) Tracking the trade in ornamental coral reef organisms: the importance of CITES and its limitations. J Aquarium Sci Conserv 3:79-94

Chen TH, Chang HC, Lue KY (2009) Unregulated trade in turtle shells for Chinese Traditional Medicine in East and Southeast Asia: the case of Taiwan. Chelonian Conserv Biol 8:11-18

Collins NM, Morris MG (1985) Threatened swallowtail butterflies of the world. The IUCN Red Data Book. IUCN, Gland

Cooney R, Jepson P (2006) The international wild bird trade: what's wrong with blanket bans? Oryx 40:1-6 Davies B (2005) Black market: inside the endangered species trade in Asia. Earth Aware Editions, San Rafael, USA 
Dinerstein E, Loucks C, Wikramanayake E et al (2007) The fate of wild tigers. Bioscience 57:508-514

Engler M, Parry-Jones R (2007) Opportunity or threat: the role of the European Union in global wildlife trade. TRAFFIC Europe, Brussels

Eudey AA (2008) The crab-eating macaque (Macaca fascicularis): widespread and rapidly declining. Primate Conserv 23:129-132

Gilardi JD (2006) Captured for conservation: will cages save wild birds? A response to Cooney \& Jepson. Oryx 40:24-26

Giles BG, Truong SK, Do HH, Vincent ACJ (2006) The catch and trade of seahorses in Vietnam. Biodivers Conserv 15:2497-2513

Green EP, Shirley F (1999) The global trade in corals. World Conservation Monitoring Centre, Cambridge

Grey M, Blais AM, Vincent ACJ (2005) Magnitude and trends of marine fish curio imports to the USA. Oryx 39:413-420

Grieser-Johns A, Thomson J (2005) Going, going, gone: the illegal trade in wildlife in East and Southeast Asia. World Bank, Washington, DC

Karesh WB, Cook RA, Gilbert M, Newcomb J (2007) Implications of wildlife trade on the movement of avian influenza and other infectious diseases. J Wildl Dis 43:55-59

Lee RJ, Gorog AJ, Dwiyahreni A et al (2005) Wildlife trade and implications for law enforcement in Indonesia: a case study from North Sulawesi. Biol Conserv 123:477-488

Li Y, Li D (1998) The dynamics of trade in live wildlife across the Guangxi border between China and Vietnam during 1993-1996 and its control strategies. Biodivers Conserv 7:895-914

Liou C (2007) The state of wildlife trade in China. TRAFFIC East Asia, China, Beijing

McNeely JA, Kapoor-Vijay P, Zhi L et al (2009) Conservation biology in Asia: the major policy challenges. Conserv Biol 23:805-810

Nekaris KAI, Nijman V (2007) CITES proposal highlights rarity of Asian nocturnal primates (Lorisidae: Nycticebus). Folia Primatol 78(3):211-214

New TR, Collins NM (1991) Swallowtail butterflies: an action plan for their conservation. IUCN, Gland

$\mathrm{Ng}$ PKL, Tan HH (1997) Freshwater fishes of Southeast Asia: potential for the aquarium fish trade and conservation issues. J Aquarium Sci Conserv 1:79-90

Nijman V (2006) In situ and ex-situ status of the Javan gibbon and the role of zoos in conservation of the species. Contrib Zool 75(3-4):161-168

Nijman V (2009) An assessment of the trade in gibbons and orang-utans on Sumatra, Indonesia. TRAFFIC Southeast Asia, Kuala Lumpur

Nijman V, Shepherd CR (2007) Trade in non-native, CITES-listed, wildlife in Asia, as exemplified by the trade in freshwater turtles and tortoises (Chelonidae) in Thailand. Contrib Zool 76(3):207-211

Nijman V, Shepherd CR (2009) Wildlife trade from ASEAN to the EU: issues with the trade in captive-bred reptiles from Indonesia. TRAFFIC Europe, Brussels

Nijman V, Shepherd CR, Mumpuni, Sanders K (2009) Over-exploitation and illegal trade of reptiles in Indonesia. Appl Herpetol 6(4): in press

Nooren H, Claridge G (2001) Wildlife trade in Laos: the end of the game. Netherlands Committee for IUCN, Amsterdam

Pantel S, Chin SY (2009) Proceedings of the workshop on trade and conservation of pangolins native to South and Southeast Asia. TRAFFIC Southeast Asia, Kuala Lumpur

Roberton SI, Bell DJ, Smith GLD et al (2006) Avian influenza H5N1 in viverrids: implications for wildlife health and conservation. Proc R Soc B 273:1729-1732

Roe D (2006) Blanket bans - conservation or imperialism? A response to Cooney \& Jepson. Oryx 40:27-28

Sadovy Y (2005) Preserving a gentle reef fish giant. Porcupine 32:5-6

Sadovy Y, Kulbicki M, Labrosse P et al (2003) The humphead wrasse, Cheilinus undulatus: synopsis of a threatened and poorly known giant coral reef fish. Rev Fish Biol Fish 13:327-364

Schlaepfer MA, Hoover C, Dodd CK (2005) Challenges in evaluating the impact of the trade in amphibians and reptiles on wild populations. Bioscience 55:256-264

Schoppe S (2009) Status, trade dynamics and management of the Southeast Asian box turtle in Indonesia. TRAFFIC Southeast Asia, Kuala Lumpur

Shepherd CR (2000) Export of live freshwater turtles and tortoises from North Sumatra and Riau, Indonesia: a case study. In: van Dijk PP, Stuart BL, Rhodin AGJ (eds) Asian turtle trade: proceedings of a workshop on conservation and trade of freshwater turtles and tortoises in Asia. Chelonian Research Monographs, vol 2. Chelonian Research Foundation, Lundberg, MA, pp 106-111

Shepherd CR (2006) The bird trade in Medan, North Sumatra: an overview. Birding ASIA 5:16-24

Shepherd CR, Nijman V (2007a) An overview of the regulation of the freshwater turtle and tortoise pet trade in Jakarta, Indonesia. TRAFFIC Southeast Asia, Kuala Lumpur 
Shepherd CR, Nijman V (2007b) An assessment of wildlife trade at Mong La market on the Myanmar-China border. TRAFFIC Bull 21:85-88

Shepherd CR, Nijman V (2008) Trade in bear parts from Myanmar: an illustration of the in-effectiveness of enforcement of international wildlife trade regulations. Biodivers Conserv 17:35-42

Shepherd CR, Shepherd LA (2009) An emerging Asian taste for owls? Enforcement agency seizes 1,236 owls and other wildlife in Malaysia. Birding ASIA 11:85

Shunichi T (2005) The state of the environment in Asia 2005-2006. Springer, Japan Environmental Council, Tokyo

Sodhi NS, Koh LP, Brook BW, Ng PKL (2004) Southeast Asian biodiversity: an impending disaster. TREE 19:654-660

Stiles D (2004) The ivory trade and elephant conservation. Environ Conserv 31:309-321

Stoett P (2002) The international regulation of trade in wildlife: institutional and normative considerations. Int Environ Agreem: Pol Law Econ 2:195-210

TRAFFIC (2008) What's driving the wildlife trade?. The World Bank, Washington

van Dijk PP, Stuart BL, Rhodin AGJ (eds) (2000) Asian turtle trade: proceedings of a workshop on conservation and trade of freshwater turtles and tortoises in Asia. Chelonian Research Monographs 2. Chelonian Research Foundation, Lunenberg, MA

Vincent ACJ (1995) Trade in seahorses for Traditional Chinese Medicines, aquarium fishes and curios. TRAFFIC Bull 15:125-128

Wang Z, Chen H, Wu D (1996) The status on live wildlife trade near the port areas in Yunnan. In: Schei PJ, Sung W, Yan X (eds) Conserving China's biodiversity. China Environmental Science Press, Beijing, pp 197-210

WCS, TRAFFIC (2004) Hunting and wildlife trade in Asia. Wildlife Conservation Society, Bali, Indonesia and TRAFFIC, New York

Wells SM, Barzdo JG (1991) International trade in marine species: Is CITES a useful control mechanism? Coast Manag 19:135-154

Wilcove DS, Koh LP (this issue) Addressing the threats to biodiversity from oil palm agriculture. Biodivers Conserv (this issue)

Wood EM (2001) Collection of coral reef fish for aquaria: global trade, conservation issues and management strategies. Marine Conservation Society, Ross-on-Wye, UK

Zhang L, Ning H, Sun S (2008) Wildlife trade, consumption and conservation awareness in southwest China. Biodivers Conserv 17:1493-1516

Zhou Z, Jiang Z (2004) International trade status and crisis for snake species in China. Conserv Biol 18:1386-1394 